Ethos: Jurnal Penelitian dan Pengabdian kepada Masyarakat, Vol 9, No.1, Januari 2021: 30-35

\title{
Pemberdayaan Remaja Sebagai Penyuluh Deteksi Dini Kanker Serviks di KABUPATEN SIAK
}

\author{
${ }^{1}$ Arfianti, ${ }^{2}$ Rahmat Azhari Kemal \\ ${ }^{1,2}$ Biologi Kedokteran, Fakultas Kedokteran, Universitas Riau, Riau, Indonesia \\ email: 'evi_anti@yahoo.com, ${ }^{2}$ rahmat.azharikemal@lecturer.unri.ac.id
}

\begin{abstract}
Cervical cancer is the fourth most common cancer in women and one of the leading causes of mortality from cancer. Early-stage cervical cancer is generally asymptomatic, therefore early detection is very important to reduce the number of patients with advanced stage of cervical cancer. Promotive and preventive efforts based on community empowerment are the best strategy to reduce the prevalence of advanced cervical cancer in Indonesia. To increase public awareness about the importance of early detection of cervical cancer requires the involvement of government, private sector and the community. Adolescents have great potential to play an active role as counselors in cervical cancer screening program. The purpose of this activity was aimed to increase the knowledge and skills of adolescents in carrying out their roles as heatlh counselors for early detection of cervical cancer. The training activities was conducted at the Minas Health Center located in the Minas District, Siak Regency on August 27, 2019. The training activities were attended by 24 (twenty four) students who serve as youth health counselor in Minas District. Analysis of training achievement showed a significant increase in the level of knowledge of participants about cervical cancer after counseling from a total knowledge score of $7.67 \pm 1.55$ to $11.00 \pm 2.21$ ( $p<0.001)$.

Keywords: Adolescent, Cervical cancer, Counselor, Early detection
\end{abstract}

\begin{abstract}
Abstrak. Kanker serviks merupakan penyakit keganasan keempat terbanyak pada wanita dan merupakan salah satu penyebab kematian terbanyak akibat kanker. Kanker serviks stadium dini pada umumnya tidak bergejala sehingga diperlukan program skrining untuk melakukan deteksi dini sehingga pasien tidak datang dalam kondisi kanker serviks stadium lanjut. Upaya promotif dan preventif berbasis pemberdayaan masyarakat merupakan strategi yang terbaik untuk menurunkan jumlah penderita kanker serviks stadium lanjut di Indonesia. Untuk meningkatkan kesadaran masyarakat tentang pentingnya deteksi dini kanker serviks diperlukan keterlibatan semua unsur dari pemerintah, swasta dan masyarakat. Oleh karena remaja merupakan kelompok yang potensial berperan secara aktif sebagai kader penyuluh deteksi kanker serviks maka tujuan kegiatan pengabdian ini adalah untuk meningkatkan pengetahuan dan keterampilan remaja dalam menjalankan peran sebagai penyuluh deteksi dini kanker serviks. Kegiatan pelatihan berlangsung di Puskemas Minas yang berada dalam wilayah Kecamatan Minas, Kabupaten Siak pada tanggal 27 Agustus 2019. Kegiatan pelatihan diikuti oleh 24 (dua puluh empat) siswi yang merupakan kader kesehatan remaja di Kecamatan Minas. Analisis tingkat ketercapaian pelatihan menunjukkan terjadinya peningkatan yang bermakna pada tingkat pengetahuan peserta tentang kanker serviks setelah penyuluhan yaitu dari total skor pengetahuan $7.67 \pm 1.55$ menjadi $11.00 \pm 2.21(p<0.001)$.
\end{abstract}

Kata Kunci: Remaja, Kanker serviks, Penyuluh, Deteksi Dini

\section{Pendahuluan}

Kanker serviks merupakan penyakit keganasan keempat terbanyak pada wanita dimana lebih dari setengah juta kasus baru didiagnosis setiap tahunnya di seluruh dunia dan 
menyebabkan lebih dari 300.000 kematian. Hampir 90\% dari kematian akibat kanker serviks terjadi di negara dengan tingkat perekonomian rendah dan berkembang (Cohen, et al., 2019). Di Indonesia, kanker serviks menempati urutan kedua sebagai penyakit kanker terbanyak pada wanita dengan angka kejadian 12,7\% (Bray, et al., 2018). Data Riset Kesehatan Dasar (Riskesdas) tahun 2018 menunjukkan adanya tren peningkatan jumlah kasus kanker di Indonesia yaitu dari 1,4 per 100.000 penduduk pada tahun 2013 menjadi 1,79 per 100.000 penduduk pada tahun 2018 (Kementerian Kesehatan Republik Indonesia, 2018).

Berdasarkan data Riskesdas tahun 2013, Provinsi Riau, Provinsi Maluku Utara, dan Provinsi Daerah Istimewa Jogjakarta merupakan provinsi dengan jumlah penderita kanker tertinggi di Indonesia dengan angka kejadian 1,5 per 100.000 penduduk. Data dari Rumah Sakit Umum Daerah (RSUD) Arifin Achmad yang merupakan rumah sakit rujukan di Provinsi Riau menunjukkan adanya peningkatan yang tajam pada jumlah penderita kanker selama periode 20142017. Berdasarkan data tersebut diketahui kanker serviks menempati peringkat kedua penyakit kanker terbanyak setelah leukemia (Riau Pos, 2018).

Vaksin HPV merupakan salah metode pencegahan kanker serviks yang sangat efektif dalam menurunkan prevalensi kanker serviks. World Health Organization merekomendasikan pemberian vaksin HPV untuk anak usia 9-13 tahun (Bray, et al., 2018). Program ini telah berhasil menekan jumlah kasus kanker serviks sebesar $38 \%$ dalam 3 tahun (Brotherton, et al., 2011).

Sebagai upaya untuk menurunkan prevalensi kanker serviks, Kementerian Kesehatan telah meluncurkan Komitmen Kegiatan
Penanggulan Kanker di Indonesia melalui upaya promotif dan preventif untuk meningkatkan kesadaran masyarakat tentang kanker. Program deteksi dini kanker serviks di fasilitas kesehatan tingkat pertama dilakukan menggunakan teknik inspeksi Visual dengan Asam Asetat (IVA) pada wanita usia 30-49 tahun setiap 3-5 tahun. Berdasarkan data Data dari Kementerian Kesehatan menunjukkan cakupan pemeriksaan IVA masih cukup rendah yaitu 2,9\% dari seluruh wanita usia 3049 tahun (Kementerian Kesehatan Republik Indonesia, 2019). Upaya skrining kanker serviks lainnya adalah melalui pemeriksaan pap smear. Program skrining kanker serviks telah diterapkan di banyak negara maju dan berdampak pada menurunnya angka kejadian kanker serviks.

Untuk mengoptimalkan upaya pencegahan dan pengendalian kanker, perlu adanya keterlibatan dari semua unsur baik pemerintah, swasta maupun masyarakat. Remaja merupakan kelompok yang potential untuk berperan serta secara aktif pada kegiatan promosi kesehatan. Intervensi kesehatan yang dilakukan sejak dini merupakan salah satu usaha strategis oleh karena proporsi remaja yang cukup besar (30\%) sebagai anggota masyarakat (Kementerian Kesehatan Republik Indonesia, 2019). Remaja tidak lagi dianggap sebagai objek program kesehatan tetapi sebagai subjek. Dengan demikian remaja diharapkan dapat lebih bertanggung jawab dalam pembangunan kesehatan. Dalam rangka menunjang peran serta remaja, terutama dalam deteksi dini kanker serviks, mereka perlu diberi bekal pengetahuan dan keterampilan untuk dapat melaksanakan fungsinya dengan baik.

Kabupaten Siak terdiri dari 14 kecamatan dan 9 desa dengan jumlah penduduk 465.414 jiwa yang terdiri atas 238.837 jiwa penduduk laki-laki dan 
226.577 jiwa penduduk perempuan. Usia produktif (15-64 tahun) mencapai $64,91 \%$. Kegiatan pengabdian kali ini akan dilakukan di salah satu desa di Kabupaten Siak.

\section{Metode}

Kegiatan pengabdian ini dilaksanakan di aula pertemuan Puskesmas Minas, Kecamatan Minas, Kabupaten Siak pada tanggal 27 Agustus 2019. Kegiatan pengabdian melibatkan 53 (lima puluh tiga) siswi SMA yang berada dalam wilayah Kecamatan Minas. Kader kesehatan remaja dipilih berdasarkan rekomendasi dari Kepala Puskesmas Minas sebagai pembina kader kesehatan remaja di sekolahsekolah yang ada di Kecamatan Minas. Kegiatan pengabdian berupa kegiatan penyuluhan dengan metode ceramah dan diskusi interaktif. Untuk mengukur efektivitas kegiatan pelatihan terhadap pengetahuan peserta, dilakukan pengukuran pengetahuan menggunakan instrumen kuesioner sebelum dan setelah penyuluhan. Kuesioner didesain untuk mengukur tingkat pengetahuan peserta tentang definisi, virus HPV, faktor risiko penularan, deteksi dini, vaksin HPV dan pengobatan kanker serviks. Pertanyaan menggunakan pilihan benar atau salah dengan penilaian angka 1 untuk jawaban benar dan angka 0 untuk jawaban salah. Selanjutkan dihitung total skor pengetahuan seluruh peserta dan disajikan dalam rerata \pm SD. Tingkat pengetahuan diukur sebelum (pretest) dan setelah (post-test) penyuluhan. Data sekunder meliputi usia dan asal sekolah juga diperoleh kuesioner. Analisis data dilakukan secara univariat dan bivariat. Analisis univariat dilakukan untuk menyajikan data dalam bentuk distribusi frekuensi sedangkan analisis bivariat digunakan untuk menguji pengaruh penyuluhan terhadap tingkat pengetahuan remaja tentang kanker serviks menggunakan Wilcoxon signed rank test. Perbedaan dianggap bermakna jika nilai $\mathrm{p}<0.05$.

\section{Hasil dan Pembahasan}

Penyuluhan dilakukan terhadap 24 (dua puluh empat) siswi yang merupakan kader kesehatan remaja yang berasal dari SMA/sederajat dan bertujuan untuk meningkatkan pengetahuan kader tentang kanker serviks (Gambar 1). Melalui penyuluhan ini diharapkan siswa dapat berperan sebagai kader di tengah masyarakat dalam meningkatkan pengetahuan tentang kanker serviks. Materi penyuluhan disampaikan menggunakan istilah-istilah yang gampang dipahami oleh masyarakat awam dan dilengkapi dengan media visual seperti gambar atau animasi untuk mempermudah pemahaman peserta tentang materi yang disampaikan. Materi penyuluhan meliputi pengertian kanker serviks, human papilloma virus (HPV) sebagai penyebab utama kanker serviks, faktor risiko penularan HPV dan gejala kanker serviks. Selain itu fokus dari materi penyuluhan adalah pentingnya pemeriksaan inspeksi visual asetat (IVA) dan pap smear sebagai salah satu strategi deteksi dini kanker serviks. Deteksi dini merupakan upaya yang sangat penting untuk meningkatkan angka harapan hidup pasien kanker serviks di Indonesia dimana sebagian besar pasien kanker serviks didiagnosis dalam stadium lanjut. Setelah penyampaian materi oleh narasumber, selanjutnya peserta diberi kesempatan untuk mengajukan pertanyaan tentang hal-hal yang masih belum dipahami dalam penyuluhan. Pertanyaan yang diajukan peserta berkaitan dengan indikasi pemeriksaan IVA dan pap smear serta gejala kanker serviks. 


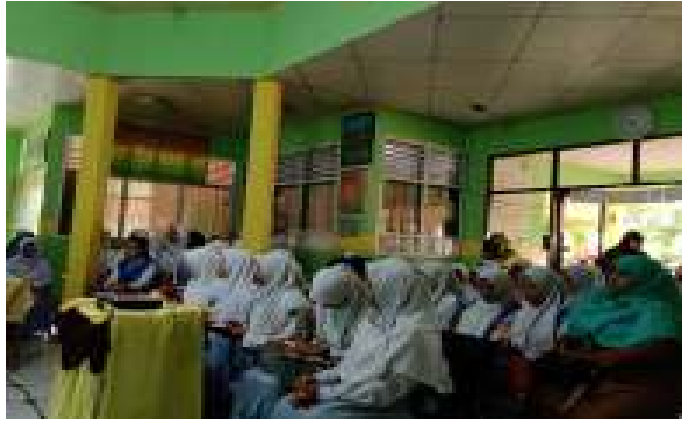

Gambar 1. Kegiatan penyuluhan kader kesehatan remaja

Untuk mengukur pengetahuan responden, hasil kuesioner pre- dan post-test dianalisis. Terdapat 24 responden yang mengisi pre- dan post-test dengan lengkap. Tabel 1 memperlihatkan karakteristik responden tersebut. Rerata usia responden adalah $16.88 \pm 0.90$ tahun. Responden paling banyak berasal dari Madrasah Aliyah (50\%), lalu diikuti oleh siswi SMA (33.311\%) dan SMK (16.67\%).

Tabel 1. Karakteristik responden

\begin{tabular}{lc}
\hline Parameter & Karakteristik \\
\hline Usia & $16.88 \pm 0.90$ tahun
\end{tabular}

Asal sekolah

$\begin{array}{ll}\text { SMA } & 8(33.3 \%) \\ \text { SMK } & 4(16.7 \%) \\ \text { MA } & 12(50 \%)\end{array}$

Seperti dapat dilihat pada Tabel 2 pengetahuan peserta tentang kanker serviks sesudah diberikan penyuluhan mengalami peningkatan yang signifikan $(p<0.001)$. Sebelum penyuluhan, rerata skor kuesioner sebesar $7.67 \pm 1.55$, tidak sampai $50 \%$ pertanyaan yang dijawab dengan benar. Setelah penyuluhan, rerata skor meningkat dengan signfikan menjadi $11.00 \pm 2.21$. Hasil penelitian ini sesuai dengan yang dilaporkan pada penelitian pada remaja putri di India dimana hanya 52\% dari 100 responden yang pernah mendengar tentang kanker serviks serta faktor risikonya. Faktor risiko yang dikenal oleh remaja putri diantaranya berganti-ganti pasangan seksual dan merokok. Hal yang menarik adalah hanya $13 \%$ yang mengetahui kanker serviks disebabkan oleh HPV (Ahlawat, 2018).

Hasil penelitian ini menunjukkan pentingnya peningkatan pengetahuan remaja tentang faktor risiko dan bahaya kanker serviks. Peningkatan pengetahuan yang didapatkan peserta pada kegiatan penyuluhan ini diharapkan dapat memberi bekal pengetahuan kepada peserta dalam menjalankan perannya sebagai kader kesehatan remaja khususnya dalam meningkatkan kesadaran masyarakat tentang pentingnya deteksi dini kanker serviks. Remaja merupakan komponen masyarakat yang sangat potensial untuk berperan secara aktif dalam menurunkan angka kejadian kanker di Indonesia sehingga perlu mendapat pelatihan untuk meningkatkan kapasitas mereka sebagai penyuluh kesehatan. Selain itu diharapkan jika secara dini mereka memiliki pengetahuan yang memadai tentang kanker serviks maka kesadaran untuk melakukan upaya deteksi dini kanker serviks akan meningkat pada saat mereka mencapai usia yang aktif secara seksual. Hal ini telah dilaporkan oleh penelitian Wantini \& Indrayani (2019) yang menunjukkan adanya hubungan positif antara pengetahuan dengan deteksi dini kanker serviks di Puskesmas Kalasan, Yogyakarta. Peningkatan pengetahuan kader melalui kegiatan penyuluhan juga telah dilaporkan sebelumnya pada kader Pos Pembinaan Terpadu Penyakit Tidak Menular (Posbindu PTM) di Kabupaten Siak (Arfianti, 2019) dan ada mitra kelompok PKK di Cilacap (Septikasari, 2018) dalam pengelolaan penyakit tidak menular. 
Tabel 2. Rerata skor pre- dan post-test kuesioner pengetahuan kanker serviks

\begin{tabular}{|c|c|c|c|}
\hline Pengetahuan & $\begin{array}{c}\text { Kisaran } \\
\text { nilai }\end{array}$ & $\begin{array}{c}\text { Rerata } \pm \\
\text { SD }\end{array}$ & $p$-value \\
\hline Pre-test & $4-11$ & $7.67 \pm 1.55$ & $p<0.001$ \\
\hline Post-test & $5-16$ & $11.00 \pm$ & \\
\hline
\end{tabular}

2.21

Perjalanan penyakit kanker serviks melewati suatu periode laten yaitu dari sejak infeksi HPV sampai keganasan terdeteksi pertama kali dan dikategorikan menjadi beberapa stadium yaitu stadium dini dan stadium lanjut. Kanker serviks stadium dini pada umumnya tidak menimbulkan gejala sehingga pasien sering terdiagnosis pada stadium lanjut. Gejala yang sering dikeluhkan pada kanker serviks stadium lanjut antara lain perdarahan setelah berhubungan seksual (contact bleeding), perdarahan vagina abnormal, atau keputihan yang berbau busuk (Cohen, et $a l ., 2019)$. Kasus kanker yang ditemukan pada stadium dini akan memberikan kesempatan pasien untuk mendapatkan pengobatan yang optimal ketika perkembangan sel kanker belum terlalu luas. Hal ini akan berdampak pada peningkatan angka harapan hidup penderita kanker. Oleh karena itu peserta yang telah mendapat penyuluhan kanker serviks diharapkan dapat menjadi duta dalam meningkatkan kesadaran masyarakat di lingkungan mereka masing-masing akan pentingnya deteksi dini kanker serviks.

\section{Kesimpulan dan Saran}

Penyuluhan kanker serviks telah dilakukan kepada remaja siswi SMA/sederajat di Kecamatan Minas. Penyuluhan ini secara signifikan meningkatkan pengetahuan siswi mengenai kanker serviks serta upaya deteksi dininya. Remaja siswi yang telah mengikuti penyuluhan tersebut diharapkan dapat menjadi berperan sebagai kader penyuluh deteksi dini kanker serviks di masyarakat. Selanjutnya perlu dilakukan pelatihan yang berkelanjutan yang melibatkan lebih banyak remaja yang diharapkan dapat menjadi garda terdepan sebagai duta penyuluh kanker serviks.

\section{DAFTAR PUSTAKA}

Ahlawat, P., Batra, N., Sharma, P., Kumar, S., \& Kumar, A. (2018). Knowledge and Attitude of Adolescent Girls and Their Mothers Regarding Cervical Cancer: A Community-Based Cross-Sectional Study. J Midlife Health, 9(3), 145149

Arfianti, Widiawaty A, Chandra F, Masdar H, Zainiar. (2019). Pemberdayaan Kader di Kecamatan Sungai Apit Kabupaten Siak dalam Deteksi Diabetes. ETHOS: Jurnal Penelitian dan Pengabdian kepada Masyarakat, 7(1): 56-63

Bray F, Ferlay J, Soerjomataram I, Siegel RL, Torre LA, \& Jemal A. (2018). Global cancer statistics 2018: GLOBOCAN estimates of incidence and mortality worldwide for 36 cancers in 185 countries. CA Cancer J Clin, 68(6), 394-424.

Brotherton JML, Fridman M, May CL, Chappell G, Saville AM, \& Gertig DM. (2011). Early effect of the HPV vaccination programme on cervical abnormalities in Victoria, Australia: An ecological study. Lancet, 377(9783), 2085-2092.

Cohen PA, Jhingran A, Oaknin A, \& Denny L. 2019. Cervical cancer. Lancet, 393(10167), 169-182.

Crosbie EJ, Einstein MH, Franceschi S, \& Kitchener HC. (2013). Human papillomavirus and cervical cancer. Lancet, 382(9895), 889-899.

Kementerian Kesehatan Republik Indonesia. 2018. Riset Kesehatan Dasar 2018. Jakarta: Kementerian Kesehatan Republik Indonesia.

Kementerian Kesehatan Republik Indonesia. 2019. Hari Kanker 
Sedunia 2019 [monograph on the internet]. Jakarta: Kementerian Kesehatan Republik Indonesia; 2019. Diunduh dari: http://www.depkes.go.id/article/vie w/19020100003/hari-kankersedunia-2019.html.

Kementerian Kesehatan Republik Indonesia. 2019. Buku KIE Kader Kesehatan Remaja. Jakarta: Kementerian Kesehatan Republik Indonesia.

Riau Pos. 2018. Penderita kanker di RSUD Arifin Achmad meningkat. Pekanbaru: Riau Pos; 2018. Diunduh dari: $\quad$ http://riaupos.co/187425berita-penderita-kanker-di-rsudarifin-achmad-meningkat-.html.

Septikasari M. (2018) Upaya Peningkatan Peran Serta Kelompok PKK dalam Pencegahan Penyakit Tidak Menular. ETHOS: Jurnal Penelitian dan Pengabdian kepada Masyarakat, 6(2): 336-342

Soler ME, Gaffikin L, \& Blumenthal PD. (2000). Cervical cancer screening in developing countries. Prim Care Update Ob Gyns, 7(3), 118-123.

Wantini N \& Indrayani N. (2019). Deteksi dini kanker serviks dengan inspeksi visual asam asetat (IVA). $J$ Ners dan Kebidanan, 6(1), 27-34.

Zhang S, McNamara M, \& Batur P. (2018). Cervical Cancer Screening: What's New? Updates for the Busy Clinician. Am J Med, 131(6), 702.e1702.e5. 